\title{
Intraoperative ventilation strategies for obese patients undergoing bariatric surgery: systematic review and meta- analysis
}

\author{
George Márcio Costa Souza ${ }^{1 *}$ D, Gianni Mara Santos², Sandra Adriana Zimpel ${ }^{1}$ and Tamara Melnik ${ }^{3}$
}

\begin{abstract}
Background: Obesity is a global epidemic, and it is widely known that increased Body mass index (BMI) is associated with alterations in respiratory mechanics. Bariatric surgery is established as an effective treatment for this condition.

Objective: To assess the safety and effectiveness of different ventilation strategies in obese patients undergoing bariatric surgery.

Methods: A systematic review of randomized clinical trials aimed at evaluating ventilation strategies for obese patients was carried out. Primary outcomes: in-hospital mortality, adequacy of gas exchange, and respiration mechanics alterations.

Results: Fourteen clinical trials with 574 participants were included. When recruitment maneuvers (RM) vs Positive endexpiratory pressure (PEEP) were compared, RM resulted in better oxygenation $p=0.03$ (MD 79.93), higher plateau pressure $p<0.00001$ (MD 7.30), higher mean airway pressure $p<0.00001$ (MD 6.61), and higher compliance $p<0.00001$ (MD 21.00); when comparing RM + Zero end-expiratory pressure (ZEEP) vs RM + PEEP 5 or $10 \mathrm{cmH} 2 \mathrm{O}$, RM associated with PEEP led to better oxygenation $p=0.001$ (MD 167.00); when comparing Continuous Positive Airway Pressure (CPAP) 40 $\mathrm{cmH} 2 \mathrm{O}+\mathrm{PEEP} 10 \mathrm{cmH} 2 \mathrm{O}$ vs CPAP $40 \mathrm{cmH} 2 \mathrm{O}+\mathrm{PEEP} 15 \mathrm{cmH} 2 \mathrm{O}, \mathrm{CPAP} 40+$ PEEP 15 achieved better gas exchange $p=$ 0.003 (MD 36.00) and compliance $p=0.0003$ (MD 3.00).
\end{abstract}

Conclusion: There is some evidence that the alveolar recruitment maneuvers associated with PEEP lead to better oxygenation and higher compliance. There is no evidence of differences between pressure control ventilation (PCV) and Volume control ventilation (VCV).

Keywords: Systematic review, Mechanical ventilation, Obesity, Meta-analysis

\section{Background}

Obesity is a global epidemic that causes major economic, social and psychological impacts [1]. Body mass index (BMI) values above $30 \mathrm{Kg} / \mathrm{m}$ [2] can result in a reduction in life expectancy similar to that caused by smoking $[2,3]$. Bariatric surgery is an effective intervention against weight gain and the majority of people who undergo such surgery show an improvement in, or the resolution of, conditions

\footnotetext{
* Correspondence: georgemarcioft@gmail.com

${ }^{1}$ Universidade Estadual de Ciências da Saúde de Alagoas - Uncisal. Pró-Reitoria de Ensino e Graduação, Rua Jorge de Lima, N 113, Trapiche, Maceió-Al, Maceio, Alagoas 57010-382, Brazil

Full list of author information is available at the end of the article
}

such as diabetes, dyslipidemia, hypertension and obstructive sleep apnaea [4].

The growing number of bariatric surgeries highlights the importance of invasive ventilator support. Anesthetic induction in obese patients can result in a significant reduction in respiratory compliance and increase resistance and pressure in the airway [5]. A correlation has also been found between a high BMI and an increase in breathing effort and a reduction in oxygenation levels, which may lead to atelectasis and slower weaning from mechanical ventilation $[6,7]$.

To date, no standard ventilation strategy has been established for obese patients, although there is some evidence that recruitment maneuvers (RM) combined with Positive

(c) The Author(s). 2020 Open Access This article is distributed under the terms of the Creative Commons Attribution 4.0 International License (http://creativecommons.org/licenses/by/4.0/), which permits unrestricted use, distribution, and reproduction in any medium, provided you give appropriate credit to the original author(s) and the source, provide a link to the Creative Commons license, and indicate if changes were made. The Creative Commons Public Domain Dedication waiver (http://creativecommons.org/publicdomain/zero/1.0/) applies to the data made available in this article, unless otherwise stated. 
End-Expiratory Pressure (PEEP) improves oxygenation and compliance in comparison with other strategies [8]. A systematic review can therefore make a significant contribution to the decision-making process of healthcare professionals, particularly surgeons and anesthesiologists, when choosing the best ventilation strategy during the surgery and anesthesia of obese patients, with the aim of reducing complications, costs and mortality.

\section{Objectives}

To assess the effectiveness and safety of different ventilation strategies for obese participants undergoing bariatric surgery under general anesthesia.

\section{Methods}

The methodology described by the Cochrane Collaboration was employed in this systematic review [9].

This research was approved by the ethics committee of the federal university of São Paulo - Unifesp - CAAE: 57099216.0.0000.5505.

\section{Criteria for considering studies for this review}

Randomized controlled trials (RCTs) that evaluated different ventilation strategies for obese patients undergoing bariatric surgery, under general anesthesia, regardless of age and gender, were included.

Obesity was defined as BMI greater than $30 \mathrm{Kg} / \mathrm{m}^{2}$ [10].

Primary outcomes: in hospital mortality, adequacy of intra-operative gas exchange, pulmonary mechanics (plateau pressure, mean airway pressures, lung compliance and lung resistance) alteration.

Secondary outcomes: Intraoperative and postoperative respiratory complications such barotrauma, hemodynamic instability, pneumonia, atelectasis, reintubation, self-extubation and the need for noninvasive mechanical ventilation measured in hours or days; cardiovascular responses; need for hospitalization in the intensive care unit (ICU) and length of stay (LOS) in the post-anesthesia care unit (PACU).

\section{Search methods for identification of studies}

Searches (see attachment) were performed in the Cochrane Central Register of Controlled Trials; MEDLINE via Ovid (1966 to present); old MEDLINE (1951 to present); and EMBASE via Ovid (January 1990 to present), without language or location restrictions. The highly sensitive Cochrane filter for randomized controlled trials was applied to the MEDLINE and EMBASE searches. Trial registers such as www.clinicaltrials.gov and the Current Controlled Clinical Trials Website (http://www.controlled-trials.com/) were also searched for ongoing trials.

\section{Data collection and analysis}

Two authors (GMCS and SAZ) independently screened all the potential studies identified and coded them as 'retrieve' (eligible or potentially eligible/unclear) or 'do not retrieve'. The full-text reports/publications were then retrieved and two authors independently screened the full text and identified the studies for inclusion. Disagreements were resolved through discussion or if required consultation with a third author. Duplicates were excluded and multiple reports of the same study were collated so that each study, rather than report, is the unit of interest in the review. The selection process was recorded in appropriate detail, as set out in the complete PRISMA flow diagram [11].

The authors were contacted and additional details were requested. Disagreements were resolved by consensus or by involving a third author.

\section{Assessment of risk of bias in the included studies}

Risk of bias was assessed at study level using Cochrane's 'Risk of Bias' tool [12]. Two review authors (GMCS and SAZ) independently assessed the methodologic quality of each study included and resolved their disagreements by discussion.

\section{Data synthesis}

To consider the measures of treatment effect for dichotomous outcomes, the total number of events within each randomized group were entered and the risk ratios with 95\% confidence intervals (CI) were calculated. For data presented in other forms, such as odds or hazard ratios, the generic variance option was used, although different effect measures (odds, risk or hazard ratios) were not combined in the same model. Mean differences were calculated for continuous outcomes measured on the same scale in different studies.

\section{Assessment of heterogeneity}

Statistical heterogeneity was evaluated by assessing forest plots and examining the $\mathrm{I}^{2}$ value, which describes the proportion of total variation across studies caused by heterogeneity rather than chance [9]. An $\mathrm{I}^{2}$ value greater than $50 \%$ was considered as the cut-off point to identify the presence of considerable heterogeneity [9].

\section{Results}

The initial search identified 1018 citations through database searches and manual searches (Fig. 1). After screening by title and abstract, full-text articles of 40 studies that were potentially eligible for inclusion in the review were obtained. A total of 25 of these were excluded due to not being randomized, presenting data in graphs, did not present data for extraction or did not respond to the PICO of this review. Following this process, fourteen studies were included in the review (Table 1). 


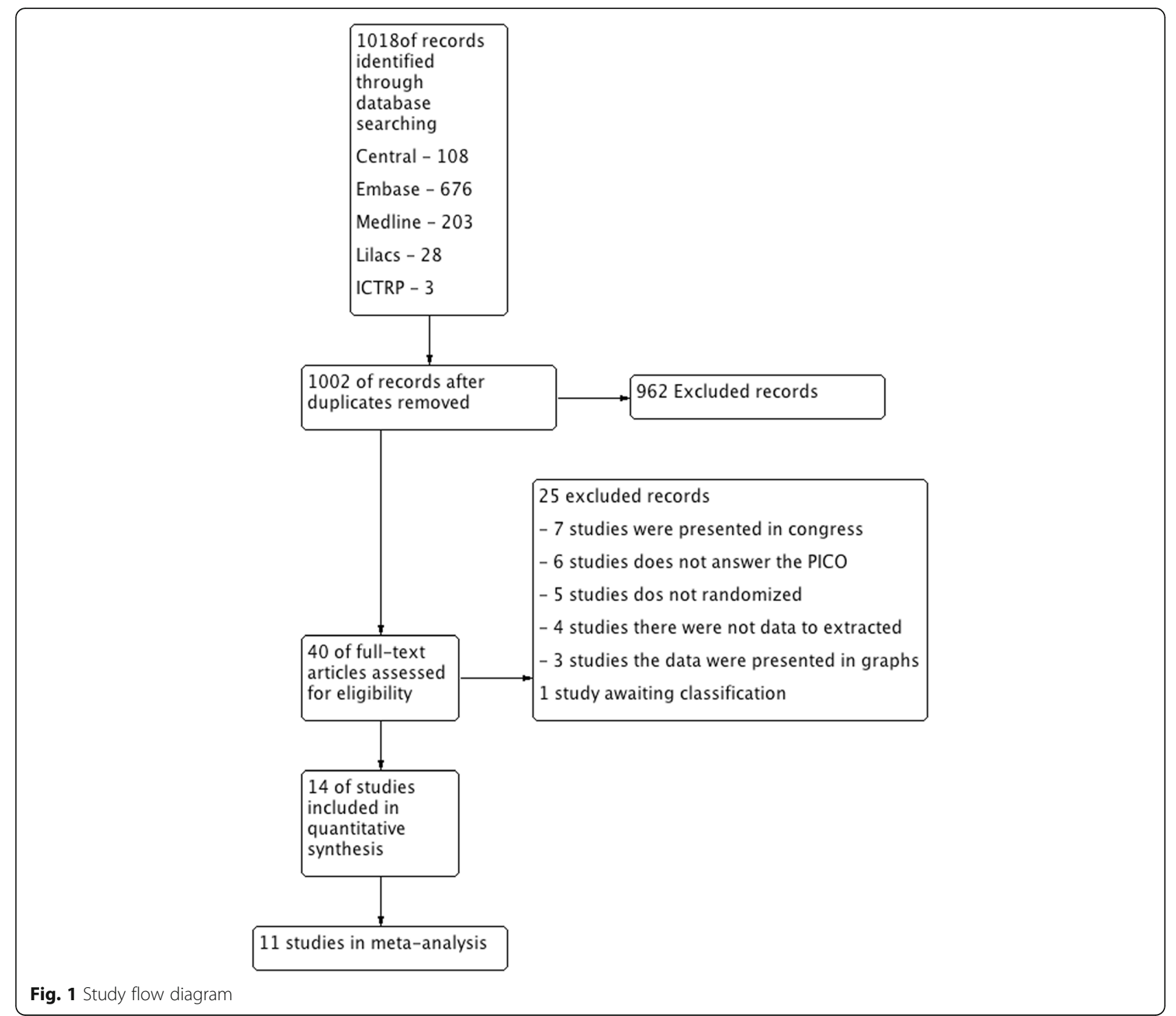

\section{Risk of bias in included studies}

Random sequence generation and allocation concealment were correctly described in seven studies $[14,17,19,20$, $22,24,25]$. In the blinding of participants and personnel domain all the studies were classified as high risk as the personnel could not be blinded. Four studies [7, 13, 17, 25 ] adequately described the blinding of outcome assessment. Eleven studies [7, 14-21, 24, 25] did not describe losses or exclusions which could cause imbalance between the groups. Only two studies $[17,21]$ employed selective reporting and while two studies $[17,25]$ presented other sources of bias Fig. 2.

\section{Effects of interventions}

Alveolar recruitment maneuvers versus PEEP only

Three studies [21, 23, 24] compared alveolar recruitment maneuvers (RM) versus PEEP to evaluate intra operative gas exchange, with the mean $\mathrm{PaO}_{2} / \mathrm{FiO}_{2}$ ratio found to be greater in the groups that underwent RM, $p=0.03$, (MD 79.93, 95\% CI 8.83 to 151.04; participants $=121$; studies $=5 ; \mathrm{I}^{2}=80 \%$,). Figure 3 shows the comparison of three different studies, separate in four subgroups, where the best results were in favor of RM Fig. 3.

Three studies [23-25] evaluated mean airway pressures by comparing RM with progressive PEEP of 10,15 and $20 \mathrm{cmH}_{2} \mathrm{O}$ versus Peep of 4 or $5 \mathrm{cmH}_{2} \mathrm{O}$ only and found that the use of PEEP without RM led to lower airway pressure, $p<0.001$ (MD 9.29, 95\% CI 5.05 to 13.53; participants $=98$; studies $=4 ; \mathrm{I}^{2}=89 \%$ ). Figure 4 shows the comparison of three different studies, separate in two subgroups, where the best results were in favor of PEEP when airway pressure was measured. Figure 4.

Two studies $[17,21]$ evaluated compliance by comparing RM with PEEP. The study by Reinius et al. [21] compared 
Table 1 Characteristics of included studies

\begin{tabular}{|c|c|c|}
\hline Study & Sample & Ventilation strategies \\
\hline Baltieri 2015 [13] & $\begin{array}{l}n=40, \text { BMl between } \\
40 \text { and } 55 \mathrm{~kg} \mathrm{~m}-2\end{array}$ & $\begin{array}{l}\text { Mode } \mathrm{VCV}, \mathrm{FiO}_{2} \text { between } 40 \\
\text { and } 60 \%, \mathrm{Vt}=6-8 \mathrm{ml} / \mathrm{kg} \text {, } \\
\mathrm{PEEP}=5 \mathrm{cmH} \mathrm{Cm}_{2} \mathrm{O} \text { (except } \\
\text { the G-intra) }\end{array}$ \\
\hline Cadi 2008 [14] & $n=36, \mathrm{BMl}>35 \mathrm{~kg} \mathrm{~m}-2$ & $\begin{array}{l}V C V: V C=8 \mathrm{ml} / \mathrm{kg} ; \mathrm{RR}=14 \\
\text { irpm; I:E = 1:2; FiO }{ }_{2}=60 \% ; \\
P E E P=5 \mathrm{cmH}_{2} \mathrm{O} \text { and } \\
\text { ispiratory pressure to keep } \\
V C=8 \mathrm{ml} / \mathrm{kg}\end{array}$ \\
\hline Chalhoub 2007 [15] & $n=52, \mathrm{BMl}>40 \mathrm{~kg} \mathrm{~m}-2$ & $\begin{array}{l}\mathrm{VCV}: \mathrm{VC}=10 \mathrm{ml} / \mathrm{kg} ; \mathrm{l}: \mathrm{E}=1: 4 ; \\
\mathrm{FiO}_{2}=40 \% ; \mathrm{RR} \text { to keep EtCO } \\
\text { between } 30 \text { and } 35 \mathrm{mmHg}\end{array}$ \\
\hline $\begin{array}{l}\text { De Baerdemaeker } \\
2008 \text { [16] }\end{array}$ & $n=24, \mathrm{BMl}>35 \mathrm{~kg} \mathrm{~m}-2$ & $\begin{array}{l}V C V: V C=10 \mathrm{ml} / \mathrm{kg}, \\
\mathrm{RR}=12 \mathrm{irpm}, \mathrm{l}: \mathrm{E}=1: 2, \\
\mathrm{PEEP}=5 \mathrm{cmH} \mathrm{H}_{2} \mathrm{O} \text { e } \\
\mathrm{FiO}_{2}=50 \%\end{array}$ \\
\hline Defresne 2014 [17] & $n=50, \mathrm{BMl}>35 \mathrm{~kg} \mathrm{~m}-2$ & $\begin{array}{l}\text { VCV: VC }=6 \mathrm{ml} / \mathrm{kg} \\
\text { PEEP }=10 \mathrm{cmH}_{2} \mathrm{O} \text { e RR to } \\
\text { keep Etco } \text { Eetween }_{2} \text { betwe } 6 \mathrm{Kpa} \text {. }\end{array}$ \\
\hline El-Sayed 2012 [18] & $n=56, \mathrm{BMl}>50 \mathrm{~kg} \mathrm{~m}-2$ & $\begin{array}{l}\text { Group 1: } \mathrm{VCV}, \mathrm{FiO}_{2}=50 \% ; \\
\mathrm{VC}=8-10 \mathrm{ml} / \mathrm{kg}^{\prime} \mathrm{I}: \mathrm{E}=1: 2 ; \\
\mathrm{PEEP}=0 \mathrm{cmH} \mathrm{C}_{2} \mathrm{O} \text { RR to keep } \\
\text { EtCO } 2 \text { between } 30 \text { and } \\
35 \mathrm{mmHg}\end{array}$ \\
\hline
\end{tabular}

$\begin{array}{ll}\text { Pré-group }(n=10): \mathrm{NPPV} & \text { Length of stay in PACU } \\ \text { before surgery for } 1 \mathrm{~h} & \\ \text { Intra group }(n=10): & \\ \mathrm{PEEP}=10 \mathrm{cmH}_{2} \mathrm{O} & \\ \text { throughout the surgery. } & \text { Gas exchange } \mathrm{PaO}_{2} / \mathrm{FiO}_{2} ; \\ \mathrm{PCV}(n=18): \mathrm{I}: \mathrm{E}=1: 2 ; & \text { Pulmonary mechanics; } \\ \mathrm{FiO}_{2}=60 \% ; \mathrm{PEEP}=5 \mathrm{cmH}_{2} \mathrm{O} & \begin{array}{l}\text { Ccardiovascular } \\ a^{2} \text { inspiratory pressure to }\end{array} \\ \text { keep VC }=8 \mathrm{ml} / \mathrm{kg} & \text { responses }\end{array}$

Group 2 ( $n=26)$ : ARM

(VCM) plus PEEP $=8 \mathrm{cmH}_{2} \mathrm{O}$.

Cardiovascular responses

VCM with pressure of $40 \mathrm{cmH}_{2} \mathrm{O}$ for $15 \mathrm{~s}$

PCV $(n=12)$ : inspiratory pressure to keep $\mathrm{VC}=$

$10 \mathrm{ml} / \mathrm{kg}$ and limited

at $35 \mathrm{cmH}_{2} \mathrm{O}, \mathrm{EtCO}_{2}$

between 35 and $40 \mathrm{mmHg}$,

PEEP $=5 \mathrm{cmH}_{2} \mathrm{O}$

MR $(n=25)$ : inspiratory

pressure $=40 \mathrm{mmHg}$ for $40 \mathrm{~s}$

twice, $5 \mathrm{~min}$ after the

pneumoperitoneum and $5 \mathrm{~min}$

after the pneumoperitoneum

plus PEEP $=10 \mathrm{cmH}_{2} \mathrm{O}$

Group 2( $n=19)$ : VCM of

$40 \mathrm{CmH}_{2} \mathrm{O}$ for $15 \mathrm{~s}$ plus

PEEP $=15 \mathrm{cmH}_{2} \mathrm{O}$.

Group $3(n=18)$ : VCM of

$40 \mathrm{CmH}_{2} \mathrm{O}$ for $15 \mathrm{~s}$ plus

PEEP $=15 \mathrm{cmH}_{2} \mathrm{O}$ plus

NPPV 12/8.

Pulmonary mechanics;

Cardiovascular responses

ulmonary mechanics

Purmonary mechanics

\section{NPPV $12 / 8$}

Group 2( $n=22):$ NPPV

Group $3(n=22)$ : NPPV

$\begin{aligned} \text { Futier E } 2011 \text { [19] } \quad n=66, \mathrm{BMl}>40 \mathrm{~kg} \mathrm{m-2} \quad & \text { Group 1: VCV, VC=8 ml/kg; } \\ & \text { RR to keep } \mathrm{PaO}_{2} \text { between } 35 \\ & \text { and } 42 \mathrm{mmHg}, \mathrm{l:E}=1: 2 ; \\ & \text { PEEP }=10 \mathrm{cmH}_{2} \mathrm{O} \text { e } \mathrm{FiO}_{2}=50 \% \\ & \end{aligned}$

$\begin{aligned} \text { Futier E } 2011 \text { [19] } \quad n=66, \mathrm{BMl}>40 \mathrm{~kg} \mathrm{m-2} \quad & \text { Group 1: VCV, VC=8 ml/kg; } \\ & \text { RR to keep } \mathrm{PaO}_{2} \text { between } 35 \\ & \text { and } 42 \mathrm{mmHg}, \mathrm{l:E}=1: 2 ; \\ & \text { PEEP }=10 \mathrm{cmH}_{2} \mathrm{O} \text { e } \mathrm{FiO}_{2}=50 \% \\ & \end{aligned}$

$\begin{aligned} \text { Futier E } 2011 \text { [19] } \quad n=66, \mathrm{BMl}>40 \mathrm{~kg} \mathrm{m-2} \quad & \text { Group 1: VCV, VC=8 ml/kg; } \\ & \text { RR to keep } \mathrm{PaO}_{2} \text { between } 35 \\ & \text { and } 42 \mathrm{mmHg}, \mathrm{l:E}=1: 2 ; \\ & \text { PEEP }=10 \mathrm{cmH}_{2} \mathrm{O} \text { e } \mathrm{FiO}_{2}=50 \% \\ & \end{aligned}$ plus ARM (after intubation)

ARM with VCM of $40 \mathrm{~cm} \mathrm{H}_{2} \mathrm{O}$ during 40s.

\begin{tabular}{|c|c|c|}
\hline Mousa 2013 [20] & $n=30, \mathrm{BMI}>40 \mathrm{~kg} \mathrm{~m}-2$ & $\begin{array}{l}\mathrm{PCV}: \mathrm{FiO}_{2}=50 \% \\
\mathrm{PEEP}=5 \mathrm{cmH}_{2} \mathrm{O} ; \\
\text { inspiratory pressure to } \\
\text { keep } \mathrm{VC} \text { with } 8 \mathrm{ml} / \mathrm{kg} ; \\
\text { RR to keep EtCO } \\
\text { between } 35 \text { and } 40 \mathrm{~mm}\end{array}$ \\
\hline Reinius 2009 [21] & $\mathrm{n}=30, \mathrm{BMI}>40 \mathrm{~kg} \mathrm{~m}-2$ & $\begin{array}{l}\text { VCV: } \mathrm{FiO}_{2}=50 \% ; \\
\mathrm{PEEP}=0 \mathrm{cmH}_{2} \mathrm{O} ; \\
\mathrm{VC}=10 \mathrm{ml} / \mathrm{kg} \\
\mathrm{RR}=12 \mathrm{irpm} \text { ou } \\
\mathrm{EtCO} \text { between } 34 \\
\text { and } 41 \mathrm{mmHg} ; \mathrm{I}: \mathrm{E}=1: 2\end{array}$ \\
\hline $\begin{array}{l}\text { Remístico P } \\
2011 \text { [22] }\end{array}$ & $\mathrm{n}=30, \mathrm{BMI} 35,6 \mathrm{~kg} \mathrm{~m}-2$ & $\begin{array}{l}\text { VCV: Details not } \\
\text { described in the article }\end{array}$ \\
\hline
\end{tabular}

I:E $(n=15)=1: 1$

Pulmonary mechanics

Cardiovascular responses

Pulmonary mechanics

Cardiovascular responses

Intraoperative and postoperative Respiratory complications

Cardiovascular responses

$\begin{array}{ll}\text { - Group ARM plus ZEEP }(n=10) & \text { Gas exchange } \mathrm{PaO}_{2} / \mathrm{FiO}_{2} \\ \text { - Group MR plus PEEP }=10 \mathrm{cmH}_{2} \mathrm{O}(n=10) & \text { Pulmonary mechanics } \\ \text { ARM was performed with } & \text { Cardiovascular responses } \\ \text { inspiratory pressure }=55 & \\ \mathrm{CmH}_{2} \mathrm{O} \text { plus inspiratory } & \\ \text { hold of } 10 \mathrm{~s}, & \\ \text { Experimental group: }(n=15): & \text { Cardiovascular responses }\end{array}$

ARM with PEEP of $30 \mathrm{cmH}_{2} \mathrm{O}$

plus inspiratory pressure of

$15 \mathrm{cmH}_{2} \mathrm{O}$ above PEEP, for

2 min, after pneumoperitoneum.

Group ARM 10, 15 and $20(n=17)$ :

progressive increase 
Table 1 Characteristics of included studies (Continued)

\begin{tabular}{|c|c|c|c|c|}
\hline Study & Sample & Ventilation strategies & Intervention & Outcomes of interest \\
\hline & & $\begin{array}{l}\mathrm{CmH}_{2} \mathrm{O} \text { e } \mathrm{FR} \text { between } \\
12 \text { and } 14 \text { irpm. }\end{array}$ & $\begin{array}{l}\text { of PEEP to } 10,15 \text { and } \\
20 \mathrm{cmH}_{2} \mathrm{O} \text { plus } 40 \text { s } \\
\text { inspiratory hold in each } \\
\text { step for } 2 \text { min. }\end{array}$ & Pulmonary mechanics \\
\hline & & & $\begin{array}{l}\text { Group ARM } 30(n=16) \text { : } \\
\text { PEEP of } 30 \mathrm{cmH}_{2} \mathrm{O} \text { for } \\
2 \text { min plus inspiratory } \\
\text { hold of } 40 \text { s. }\end{array}$ & \\
\hline & & & $\begin{array}{l}\text { After the ARM the PEEP } \\
\text { was keep in } 5 \mathrm{cmH}_{2} \mathrm{O} \text {. }\end{array}$ & \\
\hline \multirow[t]{2}{*}{ Sprung 2009 [24] } & \multirow{2}{*}{$\begin{array}{l}\mathrm{n}=20, \mathrm{BMI}= \\
>40 \mathrm{~kg} \mathrm{~m}-2\end{array}$} & \multirow{2}{*}{$\begin{array}{l}\text { VCV: RR }=8 \text { irmp (or to keep } \\
\mathrm{EtCO}_{2} \text { between } 40 \text { and } \\
45 \mathrm{mmHg} \text { ); } \mathrm{VC}=8 \mathrm{ml} / \mathrm{kg} ; \\
\mathrm{PEEP}=4 \mathrm{cmH}_{2} \mathrm{O} ; \mathrm{l}: \mathrm{E}=1: 2 ; \\
\mathrm{FiO}_{2}=50 \%\end{array}$} & \multirow[b]{2}{*}{$\begin{array}{l}\text { ARM }(n=8) \text { : progressive } \\
\text { increase of PEEP to } 4,10 \text {, } \\
15 \text { for three cycles and } \\
\text { after more } 20 \mathrm{cmH}_{2} \mathrm{O} \text { of } \\
\text { PEEP for } 10 \text { cycles, after the } \\
\text { ARM the PEEP was keep in } \\
12 \mathrm{cmH}_{2} \mathrm{O}\end{array}$} & Gas exchange $\mathrm{PaO}_{2} / \mathrm{FiO}_{2}$ \\
\hline & & & & Pulmonary mechanics \\
\hline \multirow[t]{4}{*}{ Talab 2009 [7] } & \multirow{4}{*}{$\begin{array}{l}n=58, \text { BMl between } \\
30 \text { and } 50 \mathrm{~kg} \mathrm{~m}-2\end{array}$} & \multirow{4}{*}{$\begin{array}{l}\text { VCV: } \mathrm{FiO}_{2}=50 \% ; \mathrm{VC} \\
\text { between } 8 \text { and } \\
10 \mathrm{ml} / \mathrm{kg} \text {; RR to keep } \\
\mathrm{EtCO}_{2} \text { between } 32 \text { and } \\
36 \mathrm{mmHg} \text {; }\end{array}$} & Group VCM plus ZEEP $(n=19)$ & Cardiovascular responses \\
\hline & & & $\begin{array}{l}\text { Group VCM plus } \\
\text { PEEP }=10 \mathrm{cmH}_{2} \mathrm{O}(n=20)\end{array}$ & $\begin{array}{l}\text { Intraoperative and } \\
\text { postoperative Respiratory } \\
\text { complications }\end{array}$ \\
\hline & & & $\begin{array}{l}\text { VCM was apply for } 7-8 \mathrm{~s} \\
\text { after intubation. }\end{array}$ & Length of stay in PACU \\
\hline & & & $\begin{array}{l}\text { The details of the VCM } \\
\text { were not described }\end{array}$ & \\
\hline \multirow[t]{3}{*}{ Whalen 2006 [25] } & \multirow[t]{3}{*}{$\mathrm{n}=20, \mathrm{BMI}>40 \mathrm{~kg} \mathrm{~m}-2$} & \multirow{3}{*}{$\begin{array}{l}V C V: \mathrm{FiO}_{2}=50 \%, \mathrm{RR}=8 \mathrm{irpm} ; \\
V C=8 \mathrm{ml} / \mathrm{kg} ; \mathrm{PEEP}=4 \mathrm{CmH}_{2} \mathrm{O} \\
\mathrm{l}: \mathrm{E}=1: 2\end{array}$} & \multirow{2}{*}{$\begin{array}{l}\text { ARM }(n=10) \text { : progressive } \\
\text { increase of PEEP to } 4,10,15 \\
\text { for three cycles and after } \\
\text { more } 20 \mathrm{cmH}_{2} \mathrm{O} \text { of PEEP } \\
\text { for } 10 \text { cycles. }\end{array}$} & Pulmonary mechanics \\
\hline & & & & $\begin{array}{l}\text { Intraoperative and } \\
\text { postoperative Respiratory } \\
\text { complications }\end{array}$ \\
\hline & & & $\begin{array}{l}\text { The number of } \mathrm{ARM} \\
\text { depended of the } \mathrm{PaO}_{2} \text {. } \\
\text { After ARM the PEEP was } \\
\text { keep in } 12 \mathrm{cmH}_{2} \mathrm{O} \text {. }\end{array}$ & \\
\hline
\end{tabular}

Legends: BMI: Body Mass Index; NPPV: noninvasive positive pressure ventilation; VCM: vital capacity maneuvers; VCV: volume-controlled ventilation; PCV: Pressurecontrolled ventilation; $\mathrm{FiO}_{2}$ : inspired fraction of oxygen; RR: respiratory rate; $\mathrm{V}_{\mathrm{t}}$ : tidal volume; PEEP: positive end-expiratory pressure; ZEEP: zero end-expiratory pressure; I:E: inspiratory-to-expiratory ratio; ARM: alveolar recruitment maneuvers; $\mathrm{ETCO}_{2}$ : end-tidal $\mathrm{CO}_{2}$; VCM: viral capacity maneuver; PIP: peak inspiratory pressure

RM with $55 \mathrm{cmH}_{2} \mathrm{O}$ CPAP plus $10 \mathrm{cmH}_{2} \mathrm{O}$ PEEP versus 10 $\mathrm{cmH}_{2} \mathrm{O}$ of PEEP only, and identified greater compliance when using RM plus PEEP, $p<0.00001$ (MD 21.00, 95\% CI 12.92 to 29.08; participants $=20$; studies $=1 ; \mathrm{I}^{2}=0 \%$ ). The same study by Reinius et al. [21] also compared RM with
CPAP $55 \mathrm{cmH}_{2} \mathrm{O}$ plus ZEEP versus PEEP with $10 \mathrm{cmH}_{2} \mathrm{O}$, only and found no difference between the groups for compliance, $p=0.49$ (MD 2.00, 95\% CI -3.71 to 7.71; participants $=20$; studies $=1 ; \mathrm{I}^{2}=0 \%$ ). The study by Defresne et al. [17] compared RM with CPAP of $40 \mathrm{cmH}_{2} \mathrm{O}$ plus

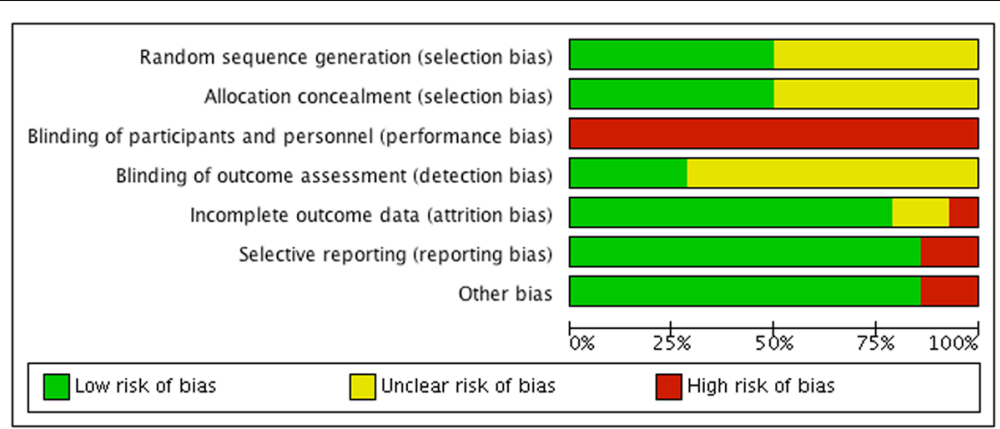

Fig. 2 Risk of bias graph: review authors' judgements about each risk of bias item presented as percentages across all included studies 


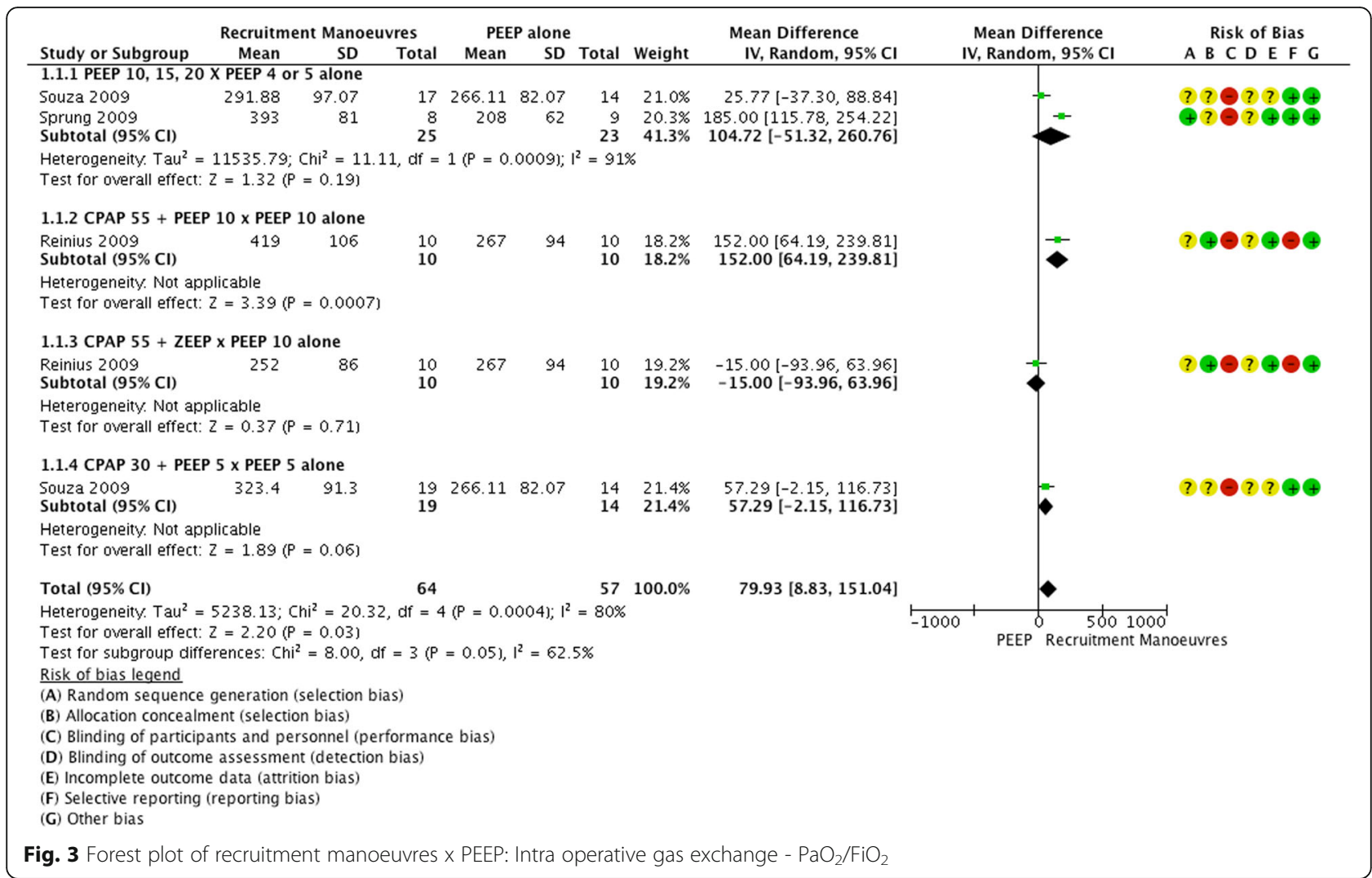

PEEP $10 \mathrm{cmH}_{2} \mathrm{O}$ versus $10 \mathrm{cmH}_{2} \mathrm{O}$ of PEEP only and found greater compliance when using RM plus PEEP, $P<$ 0.00001 (MD 24.00, 95\% CI 15.73 to 32.27; participants = 50 ; studies $\left.=1 ; \mathrm{I}^{2}=0 \%\right)$. When all the studies were taken together, the groups receiving RM exhibited better pulmonary compliance, $p<0.04$, (MD 15.42, 95\% CI 0.64 to 30.20 ; participants $=90$; studies $=3 ; \mathrm{I}^{2}=92 \%$,). Figure 5 shows the comparison of two different studies, separate in three subgroups, where the best results were in favor of RM when pulmonary compliance was measured. Figure 5.

Four studies [15, 19, 21, 22] evaluated mean arterial pressure. The studies by Chalhoub et al. [15]; Futier et al. [19] and Reinius et al. [21] compared RM with CPAP of 40 or $55 \mathrm{cmH}_{2} \mathrm{O}$ versus 8 or $10 \mathrm{cmH}_{2} \mathrm{O}$ of PEEP only and

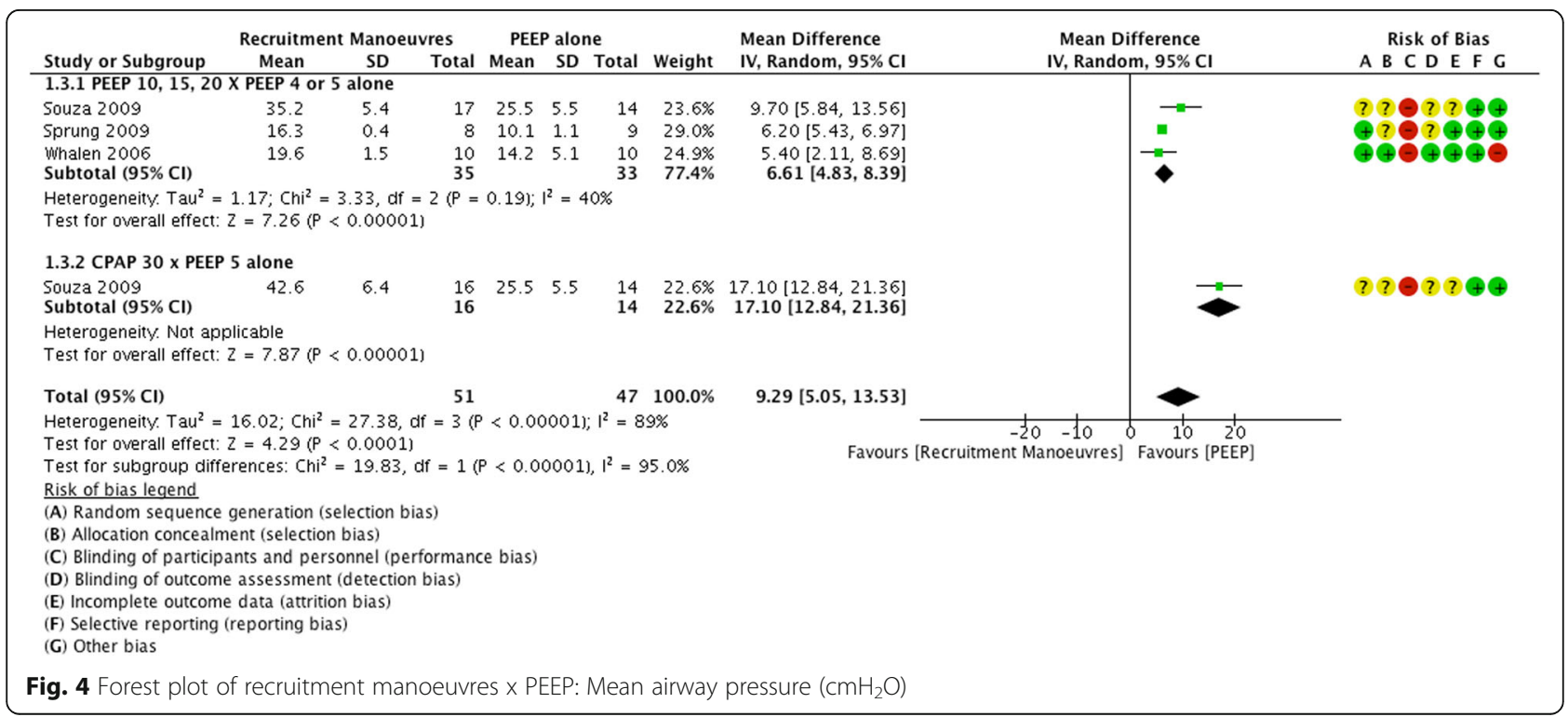




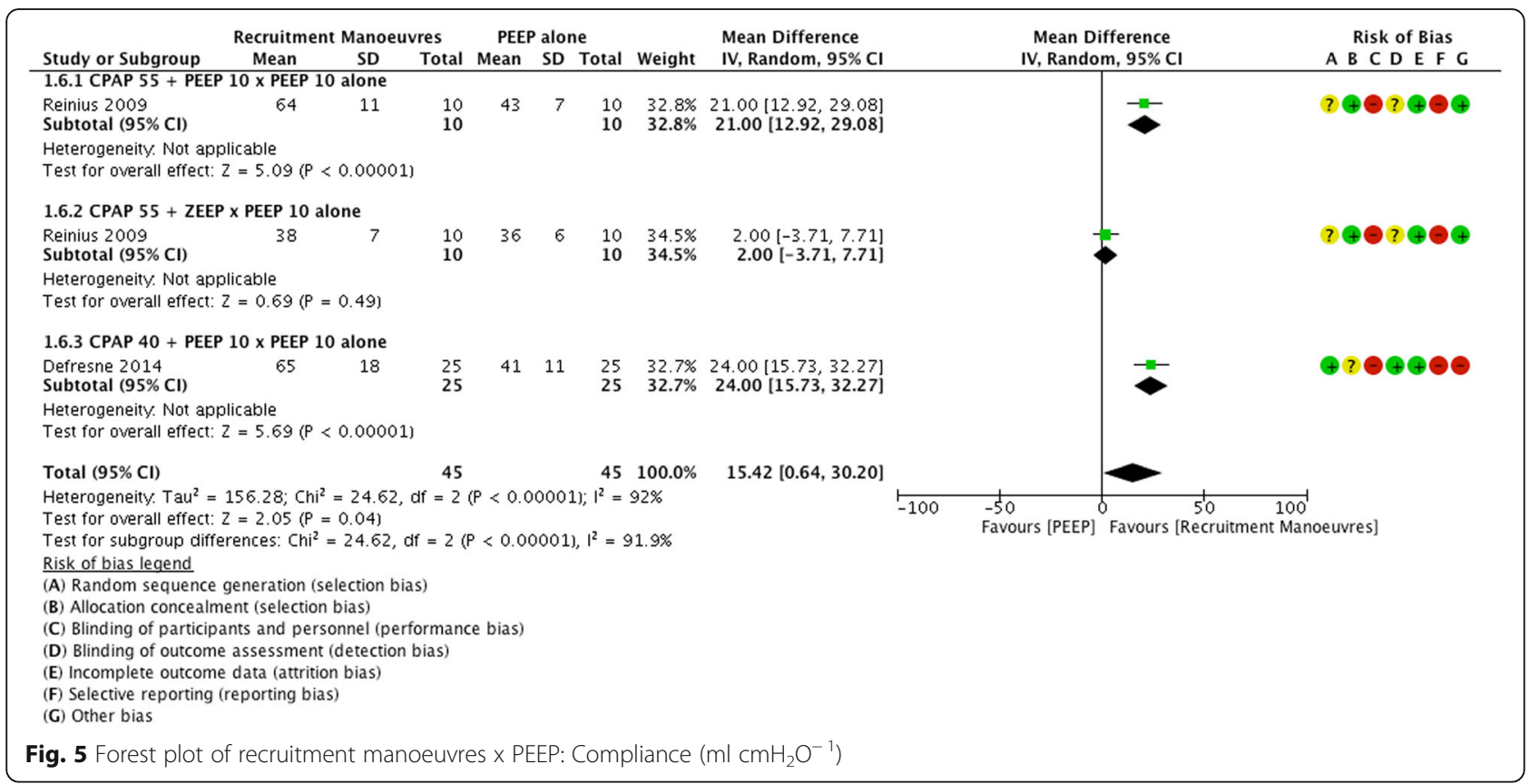

found no difference between the groups, $p=0,84$, (MD $0.87,95 \% \mathrm{CI}-3.77$ to 5.52 ; participants $=116$; studies $=3$; $\mathrm{I}^{2}=0 \%$ ). The study by Remístico et al. [22] compared a group with RM combined with inspiratory pressure of 15 $\mathrm{cmH}_{2} \mathrm{O}$ and $30 \mathrm{cmH}_{2} \mathrm{O}$ of PEEP versus PEEP of $5 \mathrm{cmH}_{2} \mathrm{O}$ only, and found no difference between the mean arterial pressure of the groups, $p=0.41$, (MD $4.00,95 \%$ CI -5.45 to 13.45 ; participants $=30$; studies $\left.=1 ; \mathrm{I}^{2}=0 \%\right)$. The study by Reinius et al. [21] compared a group receiving RM with CPAP of $55 \mathrm{cmH}_{2} \mathrm{O}$ plus ZEEP versus $10 \mathrm{cmH}_{2} \mathrm{O}$ PEEP only, and also found no difference between the mean arterial pressure of the groups, $p=0.74$, (MD 2.00, 95\% CI 9.69 to 13.69 ; participants $=20$; studies $\left.=1 ; \mathrm{I}^{2}=0 \%\right)$. When all the studies were grouped there was no difference in mean arterial pressure between RM versus the use of PEEP without RM, $p=0.44$, (MD 1.54, 95\% CI -2.39 to 5.47; participants $=166$; studies $\left.=5 ; \mathrm{I}^{2}=0 \%\right)$.

\section{Pressure control ventilation versus volume control ventilation}

Of the two included studies that evaluated this comparison [14, 16], only the study by Cadi et al. [14] evaluated the $\mathrm{PaO}_{2} / \mathrm{FiO}_{2}$ ratio, finding that the PCV mode achieved greater oxygenation than the VCV mode, $p=0.007$, (MD 82.00, 95\% CI 21.90 to 142.10 ; participants $=36 ;$ studies $=1 ; \quad I 2=0 \%)$. The study by De Baerdemaeker et al. [16] did not identify differences in the variables analyzed.

No differences were found between the VCV and PCV modes in the evaluation of mean airway pressure, plateau pressure, lung compliance, lung resistance and arterial pressure.

\section{Alveolar recruitment maneuver plus ZEEP versus the same RM plus 5 or $10 \mathrm{CmH}_{2} \mathrm{O}$ of PEEP}

The study by Reinius et al. [21] compared RM with $55 \mathrm{cmH}_{2} \mathrm{O}$ CPAP plus ZEEP versus the same RM plus $10 \mathrm{cmH}_{2} \mathrm{O}$ of PEEP and found an improvement in oxygenation in the group with RM plus PEEP 10 $\mathrm{cmH}_{2} \mathrm{O} \quad p=0.001$, (MD 167.00, 95\% CI 82.40 to 251.60; participants $=20$; studies $=1 ; \mathrm{I}^{2}=0 \%$ ) and in compliance $p<0.00001$, (MD 26.00, 95\% CI 17.92 to 34.08; $\quad$ participants $=20 ; \quad$ studies $=1 ; \quad \mathrm{I}^{2}=0 \% \quad$ when PEEP of $10 \mathrm{cmH}_{2} \mathrm{O}$ was used.

The study by Talab et al. [7] evaluated the length of stay (LOS) in the post- anesthesia care unit (PACU), comparing the RM with CPAP $40 \mathrm{cmH}_{2} \mathrm{O}$ plus ZEEP versus $\mathrm{RM}$ with CPAP $40 \mathrm{cmH}_{2} \mathrm{O}$ followed by PEEP 10 $\mathrm{cmH}_{2} \mathrm{O}$ and found a shorter LOS in the PACU in the RM plus PEEP group, $p=0.02$, (MD -21.05, 95\% CI 38.90 to -3.20 ; participants $=39$; studies $=1 ; \mathrm{I}^{2}=0 \%$ ), The same authors compared RM with $40 \mathrm{cmH}_{2} \mathrm{O}$ CPAP plus ZEEP versus ARM with $40 \mathrm{cmH}_{2} \mathrm{O}$ CPAP plus 5 $\mathrm{cmH}_{2} \mathrm{O}$ PEEP and found no difference between the LOS in PACU of the groups, $p=0.26$, (MD -10.45, 95\% CI 28.78 to 7.88 ; participants $=38 ; \quad$ studies $\left.=1 ; \mathrm{I}^{2}=0 \%\right)$. When the two comparisons were pooled the shortest LOS in the PACU was found in the group that received RM plus PEEP, $p=0.01$, (MD $-15.89,95 \% \mathrm{CI}-28.68$ to - 3.10; participants $=77$; studies $=2 ; \mathrm{I}^{2}=0 \%$ ).

The study by Talab et al. [7] compared RM with CPAP $40 \mathrm{cmH}_{2} \mathrm{O}$ plus ZEEP versus RM with CPAP $40 \mathrm{cmH}_{2} \mathrm{O}$ plus PEEP $10 \mathrm{cmH}_{2} \mathrm{O}$ and found fewer patients with lamellar atelectasis in the group that received RM plus ZEEP, $p=0.007$, (RR 5.22, 95\% CI 1.33 to 20.55; participants $=39$; 
studies $=1 ; \mathrm{I}^{2}=0 \%$ ). The same author Talab et al. [7] compared RM with CPAP $40 \mathrm{cmH}_{2} \mathrm{O}$ plus ZEEP versus $\mathrm{RM}$ with CPAP $40 \mathrm{cmH}_{2} \mathrm{O}$ plus PEEP $5 \mathrm{cmH}_{2} \mathrm{O}$ and found no difference in lamellar atelectasis between the groups, $p=$ 0.38, (RR 2.00, 95\% CI 0.41 to 9.65; participants $=38$; studies $\left.=1 ; I^{2}=0 \%\right)$. When the two comparisons were pooled there was a smaller proportion of lamellar atelectasis in the group that underwent RM plus ZEEP, $p=0.03$, (RR 3.45, 95\% CI 1.23 to 9.71; participants $=77$; studies $=2 ; \mathrm{I}^{2}=0 \%$ ). When Talab et al. [7] evaluated RM with CPAP $40 \mathrm{cmH}_{2} \mathrm{O}$ plus ZEEP versus RM with CPAP $40 \mathrm{cmH}_{2} \mathrm{O}$ plus PEEP 10 $\mathrm{cmH}_{2} \mathrm{O}$, fewer patients with segmental atelectasis were found in the group that received RM plus $10 \mathrm{cmH}_{2} \mathrm{O}$ PEEP, $p=0.009$, (RR 0.29, 95\% CI 0.12 to 0.74; participants $=39$; studies $\left.=1 ; \mathrm{I}^{2}=0 \%\right)$.

Talab et al. [7] also compared RM with CPAP 40 $\mathrm{cmH}_{2} \mathrm{O}$ plus PEEP $5 \mathrm{cmH}_{2} \mathrm{O}$ versus RM with CPAP 40 $\mathrm{cmH}_{2} \mathrm{O}$ plus PEEP $10 \mathrm{cmH}_{2} \mathrm{O}$ and found a difference between the groups, with a lower number of patients with Lamellar atelectasis in the RM plus PEEP $5 \mathrm{cmH}_{2} \mathrm{O}$ group, $p=0.05$, (RR 2.61, 95\% CI 1.00 to 6.80 ; participants $=39$; studies $\left.=1 ; \mathrm{I}^{2}=0 \%\right)$.

\section{CPAP 40 plus PEEP10 versus CPAP 40 plus PEEP 15}

El-Sayed et al. [18] compared CPAP $40 \mathrm{cmH}_{2} \mathrm{O}$ plus PEEP $10 \mathrm{cmH}_{2} \mathrm{O}$ versus CPAP $40 \mathrm{cmH}_{2} \mathrm{O}$ plus PEEP 15 $\mathrm{cmH}_{2} \mathrm{O}$ and found that CPAP plus PEEP $15 \mathrm{cmH}_{2} \mathrm{O}$ achieved a greater $\mathrm{PaO}_{2} / \mathrm{FiO}_{2}$ ratio, $p=0.003$, (MD 36.00 , $95 \%$ CI 12.10 to 59.90 ; participants $=38$; studies $=$ $\left.1 ; \mathrm{I}^{2}=0 \%\right)$ and greater lung compliance $\mathrm{cmH}_{2} \mathrm{O}, p=$ 0.0003, (MD 3.00, 95\% CI 1.38 to 4.62; participants $=38$; studies $\left.=1 ; \mathrm{I}^{2}=0 \%\right)$.

\section{Alveolar recruitment maneuver plus PEEP 10, 15 and 20 versus CPAP 30}

The study by Souza et al. [23] compared the use of RM with progressive PEEP of 10,15 and $20 \mathrm{cmH}_{2} \mathrm{O}$ versus CPAP $30 \mathrm{cmH}_{2} \mathrm{O}$ and found that the RM with progressive PEEP obtained lower mean airway pressures, $\mathrm{p}=$ 0.0003, (MD -7.40, 95\% CI -11.45 to -3.35 ; participants $=33$; studies $=1 ; \mathrm{I}^{2}=0 \%$ ).

\section{PEEP 10 versus PEEP 5}

The study by Baltieri et al. [13] compared the use of PEEP $10 \mathrm{cmH}_{2} \mathrm{O}$ versus PEEP $5 \mathrm{cmH}_{2} \mathrm{O}$ and found no difference between the groups in LOS in the PACU, $p=$ 0.21, (MD 36.00, 95\% CI -20.16 to 92.16; participants = 30 ; studies $=1 ; \mathrm{I}^{2}=0 \%$ ).

\section{I:E 1:1 ratio versus I:E 1:2 ratio}

The study by Mousa et al. [20] evaluated the I:E 1:1 ratio versus the I:E 1:2 ratio and found that the I:E 1: 1 ratio group achieved greater lung compliance than the group with a I:E 1:2 ratio, $p=0.01$, (MD 4.67,
95\% CI 1.06 to 8.28; participants $=30$; studies $=1 ; \mathrm{I}^{2}=$ $0 \%$, low-quality evidence).

\section{Discussion}

The present systematic review evaluated different ventilatory strategies for obese patients undergoing bariatric surgery, such as: comparison between PCV and VCV; comparison of different forms of RM, different PEEP levels and comparison between I:E 1:1 ratio and I:E 2:2. Fourteen studies with a total of 574 participants were included.

Significant variability in interventions were found. This demonstrates the lack of consensus on how to ventilate obese patients undergoing surgery, corroborating a review published by Aldenkortt et al. [8]

The main finding of the present study is the evidence that obese patients receiving mechanical ventilation benefit from RM, especially when combined with PEEP, as evidenced by improvements in oxygenation and respiratory compliance. While it was observed in this systematic review that the isolated use of PEEP was more effective when higher values were used, however the best result was the combination of the RM with higher levels of PEEP. In addition to these findings, no difference was found between VCV and PCV modes of ventilation in all analyzed outcomes, corroborating another study by Aldenkortt et al. [8]. No respiratory complications or major adverse events were reported in the studies included in this review. Such findings are similar to those found by Aldenkortt et al. [8]. and $\mathrm{Hu}$ et al. [26]. Recent guidelines regarding mechanical ventilation of patients with acute respiratory distress syndrome (ARDS) have shown that the incidence of complications associated with diferent mechanical ventilation strategies is low [27].

There is insufficient evidence to support differences between VCV and PCV in the evaluated outcomes. While the study by Cadi et al. [14]. Showed that the pressure controlled mode led to a higher $\mathrm{PaO}_{2} / \mathrm{FiO}_{2}$ ratio than the volume controlled mode, the study by De Baerdemaeker et al. [16]. Did not identify a difference in $\mathrm{PaO}_{2}$ between the two modes.

Three studies [17, 24, 25] included in this review describe the performance of more than one alveolar recruitment maneuver. There is no consensus on the ideal number of alveolar recruitment maneuvers regarding frequency and repetitions, however, the use of various maneuvers with patients with ARDS is associated with decreased pulmonary shunt and increased compliance [27].

Despite the wide variety of interventions and outcomes evaluated, the present review provides some evidence that the use of PEEP effectively improves oxygenation and compliance of the respiratory system. Better results seem to be achieved, however, when it is combined with 
alveolar recruitment maneuvers, and the absence of adverse effects shows that it is an effective and safe strategy for obese patients undergoing bariatric surgery. Briel et al. [28] published a systematic review and metaanalysis comparing the use of high versus low PEEP values for ARDS patients, and concluded that the use of high levels of PEEP was associated with lower hospital mortality in this group of patients. The American Thoracic Society also currently recommends the use of high levels of PEEP for patients with ARDS [27].

One study compared I:E 1:1 ratio with I:E 1:2 ratio and found that only the 1:1 ratio only improved lung compliance [20]. Few studies evaluated the use of the I:E 1:1 ratio, while some studies evaluated different inverted ratios in patients with ARDS, with conflicting results regarding its effectiveness [29-31].

\section{Limitations}

Important methodological limitations of the studies included reduced the certainty of the evidence offered by most of the included trials. Many of the trials were small and included different outcome measures, and selective outcome reporting was occasionally an issue.

The paucity of long-term follow-up data, the small sample sizes, and the heterogeneous nature of the measured outcomes limit the generalizability of the results.

\section{Conclusions}

There is evidence that alveolar recruitment maneuvers plus PEEP improve gas exchange with an increase in respiratory system compliance. The quality of such evidence is low, however.

There is no evidence to support that there is a difference between the volume and pressure controlled modes.

The various interventions assessed were shown to be safe with no major adverse events reported.

\section{Abbreviations \\ ARM: Alveolar recruitment maneuvers; BMI: Body mass index; Cl: Confidence intervals; CPAP: Continuous Positive Airway Pressure; I:E: Inspiratory:Expiratory ratio; ICU: Intensive care unit; LOS: Length of stay; MD: Mean difference; PACU: Post-anesthesia care unit; PCV: Pressure control ventilation; PEEP: Positive end-expiratory pressure; PICO: Problem, intervention, control, outcome; RCTs: Randomized controlled trials; RM: Recruitment maneuvers; UNIFESP: Universidade Federal de São Paulo; VCV: Volume control ventilation; ZEEP: Zero end-expiratory pressure \\ Acknowledgements \\ This research was partially supported by governmental foundation Coordenação de Aperfeiçoamento de Pessoal de Nível Superior (CAPES). We are grateful to Universidade Estadual de Ciências da Saúde de Alagoas (UNCISAL) for the institutional support. We are thankful to our colleague Dr. Alvaro Atallah who provided expertise that greatly assisted this systematic review.}

\section{Authors' contributions}

GMCS - corresponding author and major reseacher. GMS - statistician expert. SAZ - second researcher for data extraction. TM - methodology expert. All authors read and approved the final manuscript.

\section{Funding}

This research was partially supported by governmental foundation Coordenação de Aperfeiçoamento de Pessoal de Nível Superior (CAPES) which is a government agency. The funding was used for articles translation to Portuguese. Theare were no role of the funding body in the design of the study and collection, analysis, and interpretation of data.

\section{Availability of data and materials}

Not applicable. All data from this systematic review were extracted from primary studies. The datasets used and/or analysed during the current study are available from the corresponding author on reasonable request.

Ethics approval and consent to participate

This research was approved by the ethics committee of the federal university of São Paulo - Unifesp - CAAE: 57099216.0.0000.5505.

Consent for publication

Not applicable.

\section{Competing interests}

The authors declare that they have no competing interests.

\section{Author details}

'Universidade Estadual de Ciências da Saúde de Alagoas - Uncisal. Pró-Reitoria de Ensino e Graduação, Rua Jorge de Lima, N 113, Trapiche, Maceió-Al, Maceio, Alagoas 57010-382, Brazil. universidade Federal de São Paulo - Unifesp, Pró Reitoria de Pós-Graduação, Rua Botucatu, $7403^{\circ}$ andar Sala 305, Vila Clementino, Sao Paulo, Brazil. ${ }^{3}$ Universidade Federal de São Paulo - Unifesp. Programa de Pos-graduacao em Saude Baseada em Evidências, Rua Botucatu, $7403^{\circ}$ andar Sala 305, Vila Clementino, Sao Paulo, SP 04023-900, Brazil.

Received: 23 February 2019 Accepted: 10 January 2020

Published online: 04 February 2020

\section{References}

1. Mathus-Vliegen L, Toouli J, Fried M, Khan AG, Garisch J, Hunt R, et al. World gastroenterology organization global guidelines on obesity. J Clin Gastroenterol. 2012;46(7):555-61.

2. Peeters A, Barendregt JJ, Willekens F, Mackenbach JP, Al Mamun A, Bonneux L, NEDCOM. The Netherlands epidemiology and demography compression of morbidity research group. Obesity in adulthood and its consequences for life expectancy: a life-table analysis. Ann Intern Med. 2003;138(1):24-32.

3. Prospective Studies Collaboration. Body-mass index and cause-specific mortality in 900000 adults: collaborative analyses of 57 prospective studies. Lancet. 2009:373:1083-96.

4. Buchwald H, Avidor $Y$, Braunwald E, Jensen MD, Pories W, Fahrbach $K$, et al. Bariatric surgery. A systematic review and meta-analysis. JAMA. 2004;292:1724-37.

5. Salihoglu T, Salihoglu Z, Zengin AK, Taskin M, Colakoglu N, Babazade R. The impacts of super obesity versus morbid obesity on respiratory mechanics and simple hemodynamic parameters during bariatric surgery. Obes Surg. 2013;23(3):279-83.

6. Pelosi P, Croci M, Ravagnan I, Tredici S, Pedoto A, Lissoni A, Gattinoni L. The effects of body mass on lung volumes, respiratory mechanics, and gas exchange during general anesthesia. Anesth Analg. 1998;87(3):654-60.

7. Talab HF, Zebani IA, Abdelrahman HS, Bukhari WL, Mamoun I, Ashour MA, et al. Intraoperative ventilatory strategies for prevention of pulmonar atelectasis in obese patients undergoing laparoscopic bariatric surgery. Anesth Analg. 2009;109(5):1511-6.

8. Aldenkortt M, Lysakowski C, Elia N, Brochard L, Tramèr MR. Ventilation strategies in obese patients undergoing surgery: a quantitative systematic review and meta-analysis. Br J Anaesth. 2012;109(4):493-502.

9. Higgins JPT, Green S (editors). Cochrane Handbook for Systematic Reviews of Interventions Version 5.1.0 [updated March 2011]. The Cochrane Collaboration, 2011. Available from www.cochrane-handbook.org.

10. American Society for Matabolic and Bariatric Surgery\{https://asmbs.org\}. Bariatric Surgery in Classl Obesity \{accessed 21 March 2020\}. Avaliable from http://asmbs.org/resources/bariatric-surgery-in-class-i-obesity.

11. Moher D, Liberati A, Tetzlaff J, Altman DG. Preferred reporting items for systematic reviews and meta-analyses: the PRISMA statement. Ann Intern Med. 2009;151(4):264-9. 
12. Higgins JPT AD, Sterne, JAC (editors). Chapter 8: Assessing risk of bias in included studies. In: In: Higgins JPT GSe, editor: Cochrane Handbook for Systematic Reviews of Interventions. Version 5.1.0 [updated March 2011]. The Cochrane Collaboration, 2011. Available from www.cochrane-handbook.org

13. Baltieri L, Santos LA, Rasera I, Montebelo MIL, Forti EMP. Use of positive pressure in pre and intraoperative of bariatric surgery and its effect on the time of extubation. Rev Bras Anestesiol. 2015;65(2):130-5.

14. Cadi P, Guenoun T, Journois D, Chevallier JM, Diehl JL, Satran D. Pressurecontrolled ventilation improves oxygenation during laparoscopic obesity surgery compared with volume- controlled ventilation. $\mathrm{Br} J$ Anaesth. 2008; 100(5):709-16.

15. Chalhoub V, Yazigi A, Sleilaty G, Haddad F, Noun R. Madi- Jebara S, et al. effect of vital capacity manoeuves on arterial oxygenation in morbidly obese patients undergoing bariatric surgery. Eur J Anaesthesiol. 2007;24(3): 283-8.

16. De Baerdemaeker LE, Van Der Herten C, Gillardin JM, Patty P, Mortier EP, Szegendi LL. Comparison of volume- controlled and pressure-controlled ventilation during laparoscopic gastric banding in morbidly obese patients. Obes Surg. 2008:18(5):680-5.

17. Defresne AA, Hans GA, Goffin PJ, Bindelle SP, Amabili PJ, DeRoover AM, Poirrier JF, Brichant JF, Joris JL. Recruitment of lung volume during surgery neither affects the postoperative spirometry nor the risk of hypoxaemia after laparoscopic gastric bypass in morbidly obese patients: a randomized controlled study. Bristsh J Anaesth. 2014;113(4):501-7.

18. El-Sayed KM, Tawfeek MM. Perioperative ventilatory strategies for improving arterial oxygenation and respiratory mechanics in morbidly obese patients undergoing laparoscopic bariatric surgery. Egyption J Anaesth. 2012;28:9-15.

19. Futier E, Constantin JM, Pelosi P, Chanques G, Massone A, Petit A, Kwiatkowski F, Bazin JE, Jaber S. Noninvasive ventilation and alveolar recruitment maneuver improve respiratory function during and after intubation of morbidly obese patients. Anesthesiology. 2011;114:135463.

20. Mousa WF. Equal ratio ventilation (1:1) improves arterial oxygenation during laparoscopic bariatric surgery: a crossover study. Saudi J Anaesth. 2013;7(1):9-13.

21. Reinius H, Jonsson L, Gustafsson S, Sundbom M, Duvemoy O, Oelosi P, et al. Prevention of atelectasis in morbidly obese oatients during general anestesia and paralysis: a computerized tomography study. Anesthesiology. 2009;111(5):979-87.

22. Remístico PPJ, Araújo S, Figueiredo LC, Aquim EE, Gomes LM, Sombrio ML, Ambiel SDF. Impact of alveolar recruitment maneuver in the postoperative period of Videolaparoscopic bariatric surgery. Rev Bras Anestesiol. 2011; 61(2):163-76.

23. Souza AP, Buschpigel M, Mathias LAST, Malheiros CA, Alves VLS. Analysis of the effects of the alveolar recruitment maneuver on blood oxygenation during bariatric surgery. Rev Bras Anestesiol. 2009;59(2):177-86.

24. Sprung J, Whalen FX, Comfere T, Bosnjak ZJ, Bajzer Z, Gajic O, Sarr MG, Schroeder DR, Liedl LM, Offord CP, Warner DO. Alveolar recruitment and arterial Desflurance concentration during bariatric surgery. Anesth Analg. 2009;108:120-7.

25. Whalen FX, Gajic O, Thompson GB, Kenfrick ML, Que FL, Williams BA, et al. The effects of the alveolar recruitment maneuver and positive endexpiratory pressure on arterial oxygenation during laparoscopic bariatric surgery. Anesth Analg. 2006;102(1):298-305.

26. Hu XY. Effective ventilation strategies for obese patients undergoing bariatric surgery a literature review: a literature review. AANA J. 2016;84(1):35-45.

27. Fan E, Del Sorbo L, Goligher EC, Hodgson CL, Munshi L, Walkey AJ, Adhikari NKJ, Amato MBP, Branson R, Brower RG e col. An official American Thoracic Society/European Society of Intensive Care Medicine/Society of Critical Care Medicine clinical practice guideline: mechanical ventilation in adult patients with acute respiratory distress syndrome. Am J Respir Crit Care Med; 2017 195(9): 1253-1263.

28. Briel M, Meade M, Mercat A, Brower RG, Talmor D, Walter SD, Slutsky AS, Pullenayegum E, Zhou Q, Cook D, et al. Higher vs lower positive endexpiratory pressure in patients with acute lung injury and acute respiratory distress syndrome: systematic review and meta-analysis. JAMA. 2010;303: 865-73.

29. Lessard MR, Guérot E, Lorino H, Lemaire F, Brochard L. Effects of pressurecontrolled with different I:E ratios versus volume-controlled ventilation on respiratory mechanics, gas exchange, and hemodynamics in patients with adult respiratory distress syndrome. Anesthesılogy. 1994;80:983-91.

30. Huang CC, Shih MJ, Tsai YH, Chang YC, Tsao TC, Hsu KH. Effects of inverse ratio ventilation versus positive end- expiratory pressure on gas exchange and gastric intramucosal PCO2 and pH under constant mean airway pressure in acute respiratory distress syndrome. Anesthesiology. 2001;95: 1182-8.

31. Gurevitch MJ, Van Dyke J, Young ES, Jackson K. Improved oxygenation and lower peak airway pressure in severe adult respiratory distress syndrome: treatment with inverse ratio ventilation. Chest. 1986;89:211.

\section{Publisher's Note}

Springer Nature remains neutral with regard to jurisdictional claims in published maps and institutional affiliations.
Ready to submit your research? Choose BMC and benefit from:

- fast, convenient online submission

- thorough peer review by experienced researchers in your field

- rapid publication on acceptance

- support for research data, including large and complex data types

- gold Open Access which fosters wider collaboration and increased citations

- maximum visibility for your research: over $100 \mathrm{M}$ website views per year

At BMC, research is always in progress.

Learn more biomedcentral.com/submissions 